\title{
Takao Ito
}

\section{Writing the Biography of Ibn Khaldūn}

\section{Introduction}

Ibn Khaldūn (732-808 H/1332-1406 CE) is undoubtedly one of the most important and prominent figures not only in the history of the Muslim world but also in world history. A huge number of studies have been conducted on Ibn Khaldūn so far, making it almost impossible to cover all of them, even if limited to his masterpiece, the Muqaddima, that is, the introduction to his history, Kitāb al'Ibar.

Nevertheless, relatively little attention has been paid to his life and biography. In his recently published biography of Ibn Khaldūn, Allen James Fromherz writes that "[t]he only existing biographies are translations of Ibn Khaldun's autobiography or cursory discussions of the outlines of his life". ${ }^{1}$ While Fromherz's book is advertised as "the first complete, scholarly biography of Ibn Khaldun in English", ${ }^{2}$ it too has relied for the most part on Ibn Khaldūn's autobiography, the Ta'rif. This also holds true for the two more recent biographical studies of Ibn Khaldūn. ${ }^{3}$

It is true that the Ta'rif is one of the most detailed autobiographies in premodern Islamic literature and provides invaluable information, as Fromherz argues, about Ibn Khaldūn himself. It is the definitive primary source for the studies on Ibn Khaldūn. As pointed out by Walter Fischel, however, the Ta'rīf does not convey “the whole, complete, and comprehensive story of his [Ibn Khaldūn's]

1 Fromherz 2010, 39.

2 Fromherz 2010, back cover.

3 Alatas 2013; Irwin 2018.

Note: This is based on a paper read at the following academic gatherings: 5 th World Congress for Middle Eastern Studies, Seville, July 2018; 2nd German-Japanese Workshop on Mamlukology, Waseda University, Tokyo, December 2018; and lastly, International Congress "The Maghrib in the Mashriq", CSIC, Madrid, December 2018. I am grateful to the participants of these gatherings for their discussions and comments, and especially to Josef Ženka for his valuable advice and help, as well as to Maribel Fierro and Mayte Penelas for giving me the opportunity to participate in their congress at the "last minute" and for inviting me to contribute to this volume. The research for this study was supported by the FY2018 Asian History Research Aid of JFE 21st Century Foundation and JSPS KAKENHI (18H00719). 
private life and activities”; rather, it is “a 'selective' account, written by Ibn Khaldūn as he wanted to be seen and judged by posterity". ${ }^{4}$ Thus, the biographies of Ibn Khaldūn by his contemporary and near-contemporary authors, which provide additional data, are no less important than the Ta'rif. Nevertheless, these "external Arabic sources" - as they are called by Fischel - most of which were produced not in Ibn Khaldūn's native region, the Maghrib, but in the Mamlūk sultanate where he spent his last years, have not yet been fully explored and evaluated. The purpose of this chapter is to examine the "external Arabic sources" on Ibn Khaldūn and their relations to each other to illumine what kind of data about Ibn Khaldūn can be learned from them. This chapter also seeks to shed light upon how their authors obtained these data. Thus, it explores how wide the intellectual networks were at the time, as well as what the relationship was between the western Arab world (the Maghrib and al-Andalus) and the eastern Arab world (the Mashriq), considering they are areas that are often treated separately.

\section{Contemporary authors in the Maghrib and al- Andalus}

The well-known vizier and historian of Granada, Lisān al-Dīn Ibn al-Khațīb (713776 H/1313-1374-5 CE), ${ }^{5}$ includes in his work on Granada, al-Ihâta fi akhbār Gharnāta, a biographical account covering Ibn Khaldūn's earlier years up to about $769 \mathrm{H} / 1367 \mathrm{CE}$ and citing a number of letters exchanged between them. ${ }^{6}$ This account includes several unique details. For instance, the genealogy of Ibn Khaldūn mentioned by Ibn al-Khațīb is slightly different from that given by Ibn Khaldūn in his Ta'rīf. ${ }^{7}$ According to Ibn al-Khațīb, Ibn Khaldūn's genealogy is 'Abd al-Raḥmān b. Muḥammad b. Muḥammad b. Muhammad b. al-Ḥasan b. Muḥammad b. Jābir b. Muḥammad b. Ibrāhīm b. Muḥammad b. 'Abd al-Raḥmān b. Khaldūn al-Haḍramī; Ibn Khaldūn, however, does not refer to Muhammad, the grandson of Khaldūn (Ibn Khaldūn's eponymous ancestor) and presents Ibrāhīm as Khaldūn's grandson. As Ibn Khaldūn admits that some of his ancestors' names

\footnotetext{
4 Fischel 1967, 162; Fischel 1956, 288.

5 On him, see Bosch-Vilá, "Ibn al-Khațîb”, $E I^{2}$; Robinson 2009; Lirola Delgado et al. 2004.

6 Ibn al-Khațīb, al-Ihāța (1965), 3: 497-516. Ibn al-Khațīb mentions in the last part of Ibn Khaldūn's biography that he sent a letter to Ibn Khaldūn in Biskra (Ibn al-Khațīb, al-Ihāṭa [1965], 516). This is presumably the letter dated 2 Jumādā I 769 H (25 December 1367 CE) that Ibn Khaldūn quotes in his autobiography (Ibn Khaldūn, al-Ta'rīf [1951], 115-122).
}

7 Ibn Khaldūn, al-Ta'rîf (1951), 1. 
are left off, his genealogy as given by Ibn al-Khațīb is certainly more accurate. Indeed, Ibn al-Khațīb's version was adopted by later biographers. Ibn al-Khațib also lists the early writings of Ibn Khaldūn, including a commentary on the Burda - the ode of the Prophet Muhammad composed by al-Būṣīin (d. 694696 H/1294-1297 CE) - and a treatise on logic, an abridgement of the Muhașșal of Fakhr al-Dīn al-Rāzī (d. 606 H/1209 CE), as well as a book on calculation. ${ }^{8}$ None of them were mentioned by any other persons including Ibn Khaldūn himself, but his holograph manuscript of Lubāb al-Muhașșal fì uṣūl al-dīn, the abridgement of Fakhr al-Dīn al-Rāzī's Muhașșal, was discovered, edited and published in 1952. Furthermore, Ibn al-Khațib provides a small but interesting piece of information on Ibn Khaldūn's private life: Ibn Khaldūn had a European concubine named Hind in Granada. ${ }^{9}$

Abū al-Walīd Ibn al-Aḥmar (ca. 725-807? H/1324-1404-5? CE) was a descendant of the Nașrid refugees to the Marīnids. ${ }^{10}$ He includes Ibn Khaldūn's qașīda poetry with a biographical note in the anthology Nathīr al-jumān, which was composed in $776 \mathrm{H} / 1374 \mathrm{CE} .{ }^{11}$ In this biographical note, Ibn al-Ahmar discusses Ibn Khaldūn's early career and praises his talents, such as his knowledge of modern and ancient history (ma'rifa bi-l-tawārīkh al-ḥadìtha wa-l-qadìma), thus indicating that Ibn Khaldūn was engaged in studying history quite early. In addition, Ibn al-Aḥmar quotes the qașida poetry which Ibn Khaldūn had sent from prison to the Marīnid ruler Abū 'Inān (r. 749-759 H/1348-1358 CE) to ask for his pardon; Ibn Khaldūn only mentions five verses of the poetry in his autobiography. ${ }^{12}$

In his biographical dictionary of the secretaries, Kitāb Mustawdi' al-'alāma wa-mustabdi' al-'allāma, Ibn al-Aḥmar describes Ibn Khaldūn as jurisprudent (faqīh), writer of the ruler's official signature (kātib 'alāma) in Tunis, and chief minister (ḥājib) in Bijāya (Béjaïa). Moreover, whereas he admires Ibn Khaldūn's

8 Ibn al-Khațî, al-Ihạța (1965), 3: 507-508; see also Rosenthal 1967, xliv-xlv; Fischel 1956, 289290.

9 Ibn al-Khațîb, al-Inạța (1965), 3: 501-507; Ibn al-Khațīb, Rayḥānat al-kuttāb (1980-81), 2: 226232; see also Grammatico 2006, 150-151.

10 On him, see Manzano Rodríguez 2009; Shatzmiller 1982, 95-105.

11 Ibn al-Aḥmar, Nathīr al-jumān (1976), 297-310; Badawī 1962, 272-279. It should be noted that Badawī mistakes Nathīr al-jumān for Ibn al-Ahmar's other work, Nathïr farā’id al-jumān fi nazm fụūl al-zamān, which contains no biographical account of Ibn Khaldūn.

12 Ibn Khaldūn, al-Ta'rîf (1951), 67. Ibn Khaldūn says that this poetry was originally about two hundred verses long, but Ibn al-Aḥmar quotes 107 verses. As Muḥammad b. Tāwit al-Ṭanjī, the editor of the Ta'riff, surmises, Ibn Khaldūn may have forgotten the number of the verses of his poem or Ibn al-Ahmar may not have quoted the entire poem, but only a part of it. See Ibn Khaldūn, al-Ta'rīf (1951), 67, n. 1. 
abilities on the one hand, he states on the other hand that Ibn Khaldūn was expelled due to his ambition for leadership. ${ }^{13}$ In the biography of Ibn Khaldūn's brother, Yahyyā, in the same work, Ibn al-Ahmmar also mentions that Yahyā's assassination was caused by Ibn Khaldūn. ${ }^{14}$ Ibn al-Aḥmar composed Mustawdi 'al'alāma after at least $789 \mathrm{H} / 1387 \mathrm{CE},{ }^{15}$ that is, after Ibn Khaldūn had presented the first version of his history to the Ḥafșid ruler Abū al-'Abbās Aḥmad II (r. 772796 H/1370-1394 CE) during 781-782 H/1379-1381 CE; ${ }^{16}$ however, Ibn al-Ahmar did not mention this work. ${ }^{17}$ Ibn al-Ahmar simply may not have known of it. Otherwise, he may have been deliberately silent; he appears to have become unsympathetic to Ibn Khaldūn later, as can be inferred from Mustawdi' al-'alāma; this was perhaps influenced by the hostile attitude of the Tunisian jurist and rival Ibn 'Arafa (716-803 H/1316-1401 CE) toward Ibn Khaldūn. ${ }^{18}$

Still Ibn Khaldūn's Muqaddima was read in the Maghrib. One of his contemporaries, Ibn al-Sakkāk (d. 818 H/1415-6 CE), who assumed the post of qā jamā' $a$ (chief judge) in Fez, used Ibn Khaldūn's ideas in his works, although he did not refer to the name of Ibn Khaldūn. ${ }^{19}$

In addition, an anecdote concerning Ibn Khaldūn is found in a biographical work on Abū 'Abd Allāh Muḥammad b. Aḥmad al-Sharīf al-Tilimsānī (710-771 H/ 1310-1-1370 CE ${ }^{20}$ and his two sons, which is assumed to have been written at the

13 Ibn al-Ahmmar, Mustawdi' al-'alāma (1964), 64-65.

14 Ibn al-Aḥmar, Mustawdi' al-'alāma (1964), 65. In 769 H/1368 CE the Zayyānid ruler Abū Ḥammū II (r. 760-791 H/1359-1389 CE) asked Ibn Khaldūn to join his court in Tlemcen. Ibn Khaldūn instead sent Yaḥyā to Tlemcen, where Yaḥyā later offended the eldest son of Abū Hammū II and was murdered in 780 H/1378-9 CE. On Yahỵā, see Bel, "Ibn Khaldūn, Abū Zakariyyā' Yaḥyā”, $E P^{2}$.

15 While Manzano Rodríguez 2009, 56, states that this work was composed between 789 H/1387 CE and 796 H/1393 CE, Shatzmiller 1982, 49, 98, speculates that it was written in 1393-1396.

16 Ibn Khaldūn, al-Ta'rîf (1951), 229-230, 233; Rosenthal 1967, lvii, cv.

17 See also Shatzmiller 1982, 49-50.

18 On Ibn 'Arafa, Muḥammad b. Muḥammad b. Muḥammad al-Warghammī, see Idris, "Ibn 'Arafa”, $E I^{2}$; Rosenthal 1967, lvi-lvii; Ibn Khaldūn, al-Ta'rîf (1951), 232-233; al-Maqrīzī, Durar al'uqūd (2002), 3: 223-225; al-Sakhāwī, al-Ḍaw' (1934-36), 9: 240-242. Abdesselam Cheddadi refers to the possibility that because of Ibn 'Arafa's hostility towards Ibn Khaldūn, the 'Ibar was "received with a resounding silence by the intellectual community" in Tunis (Cheddadi, "Ibn Khaldūn, 'Abd al-Raḥmān”, $E P^{3}$ ).

19 Benchekroun 1974, 356-357; al-Azmeh 1982, 160. On Ibn al-Sakkāk, Abū Yaḥyā Muḥammad b. Abī Ghālib (Abī al-Barakāt) al-Miknāsī al-'Iyāọī, see Ibn al-Qāḍī al-Miknāsī, Jadhwat al-iqtibās (1973), 238; Aḥmad Bābā al-Tinbuktī, Nayl al-ibtihāj (1989), 481-482; Benchekroun 1974, 383387.

20 On him, see Ibn Khaldūn, al-Ta'rîf (1951), 62-64; Aḥmad Bābā al-Tinbuktī, Nayl al-ibtihāj (1989), 430-445; on him and his family, see also Bencheneb, "al-Sharīf al-Tilimsānī”, $E I^{2}$. 
end of the 8 th/14th century. ${ }^{21}$ According to this work, Ibn Khaldūn and Ibn alSakkāk were in the house of al-Sharîf al-Tilimsānī on the day one of his sons was born in $757 \mathrm{H} / 1356 \mathrm{CE}$; al-Sharīf al-Tilimsānī made the name (ism) of his son 'Abd al-Raḥmān after Ibn Khaldūn and the agnomen (kunya) Abū Yahyā after Ibn alSakkāk. ${ }^{22}$ This anecdote indicates that the young Ibn Khaldūn was already so highly venerated by al-Shariff al-Tilimsānī that the latter named his son, who also became prominent, after him. The possibility cannot be excluded that the anecdote was fabricated later. Nevertheless, it is also recorded in another work written in the Maghrib. ${ }^{23}$ Thus, the anecdote circulated to some degree in the Maghrib, and Ibn Khaldūn was still remembered there to be at least an outstanding scholar for some time after he went to the East.

\section{Contemporary authors in the Mashriq}

In the Mashriq, particularly in Mamlūk Cairo and Damascus, we find numerous references to Ibn Khaldūn. Ta'rīkh al-duwal, the chronicle of Ibn al-Furāt (735$807 \mathrm{H} / 1334-5-1405 \mathrm{CE}$ ), the Egyptian historian, is unfortunately only fragmentally extant, and its last part covers the years from $789 \mathrm{H} / 1387 \mathrm{CE}$ to $799 \mathrm{H} /$ $1397 \mathrm{CE},{ }^{24}$ while Ibn Khaldūn arrived in Egypt in $784 \mathrm{H} / 1382 \mathrm{CE}$ and died there in 808 H/1406 CE. Nevertheless, it provides some details about Ibn Khaldūn. For example, it states that Ibn Khaldūn became a Șūfĩ at al-Khānqāh al-Baybarsiyya in Cairo in $791 \mathrm{H} / 1389$ CE for a single day, so as to be appointed shaykh of this khānqāh, following the stipulations of the founder. ${ }^{25} \mathrm{Ibn}$ al-Furāt also states that Ibn Khaldūn was one of those with whom Jamāl al-Dīn Maḥmūd b. 'Alī al-Ustādār

21 This work is entitled Manāqib al-Tilimsāniyyin by the editor, but it is more appropriately called Manāqib al-Sharîf Abī 'Abd Allāh wa-waladayhi, based on one of its manuscripts (see Manāqib al-Tilimsāniyyīn [2017], 34-37). The editor attributes the work to a son of Abū 'Abd Allāh Muhammad b. Yūsuf al-Qaysī al-Thaghrī (d. 810 H/1407-8 CE) and he further infers from the agnomen (kunya) of al-Qaysī that the author's name may have been 'Abd Allāh (Manāqib al-Tilimsāniyyīn [2017], 38-46).

22 Manāqib al-Tilimsāniyyīn (2017), 281-282.

23 Aḥmad Bābā al-Tinbuktī, Nayl al-ibtihāj (1989), 252-253 (biography of Abū Yaḥyā 'Abd alRaḥmān b. Muḥammad al-Sharīf al-Tilimsānī), and 482 (biography of Ibn al-Sakkāk). On Aḥmad Bābā al-Tinbuktī, see below.

24 On Ibn al-Furāt and his chronicle, see Massoud 2007, 34-38.

25 Ibn al-Furāt, Ta'rīkh al-duwal (1936-42), 9: 65; Fischel 1956, 293; Fischel 1967, $27-28$. 
(d. $799 \mathrm{H} / 1397 \mathrm{CE}),{ }^{26}$ the majordomo of the Mamlūk sultan Barqūq (r. 784-791 H/ 1382-1389 CE, 792-801 H/1390-1399 CE), deposited his monies. Twenty thousand dīnārs were found in Ibn Khaldūn's house when Jamāl al-Dīn Mahmūd was imprisoned and his properties were confiscated. ${ }^{27}$ Moreover, Ibn al-Furāt mentions that he learned from the Egyptian historian Ibn Duqmāq (745-809 H/1349$1407 \mathrm{CE}$ ) that Ibn Khaldūn told the latter that he had been informed of the ascent of the Hafșid ruler Abū Fāris 'Abd al-'Azīz (r. 796-837 H/1394-1434 CE) to the throne in Tunis, and the arrest of Abū Fāris's uncle who was a rival. ${ }^{28}$ Ibn Duqmāq's chronicle Nuzhat al-anām was "the backbone" of Ibn al-Furāt's Ta'rīkh alduwal. Since this text is also only fragmentally extant, it is difficult to ascertain how much Ibn al-Furāt owed to Ibn Duqmāq. However, at least some of Ibn alFurāt's accounts about Ibn Khaldūn seem to have been based on his own observations, as he was also contemporary with Ibn Khaldūn and "added his own massive material" to Ibn Duqmāq's chronicle. ${ }^{29}$

In his chronicle, the Syrian historian Ibn Hijjī (751-816 H/1350-1413 CE) ${ }^{30}$ leaves a brief obituary notice of Ibn Khaldūn. In it, Ibn Hijjī writes that Ibn Khaldūn's birthday was 23 Dhū al-Ḥijja 732 (15 September 1332) and notes having been told by al-Tādhilī that Ibn Khaldūn was seven days older than him. ${ }^{31}$ This alTādhilī or al-Tādilī can be identified as Burhān al-Dīn Ibrāhīm b. Muhammad, who was born on 29 Dhū al-Ḥijja 732/21 September 1332 and died on 18 Jumādā II 803/4 January 1401. ${ }^{32}$ Thus, Ibn Hijjī must have calculated Ibn Khaldūn's birthday, though he was off on one day - it should be 22, not 23 Dhū al-Hijja. In any case, the date provided by al-Tādhilī is not correct, since Ibn Khaldūn himself gives the other date, as will be seen below.

The Syro-Egyptian scholar, official, and historian al- 'Aynī (762-855 H/1361$1451 \mathrm{CE})^{33}$ includes a relatively detailed necrology of Ibn Khaldūn in his chronicle,

26 On him, see Ibn al-Furāt, Ta'rīkh al-duwal (1936-42), 9: 477; Ibn Ḥajar al-'Asqalānī, al-Durar (1993), 4: 329; Ibn Taghrībirdī, al-Manhal (1984-2009), 11: 213-214. For the ustādār al- 'âliya/alsulțān (the supreme/sultanic majordomo) in the Mamlūk sultanate, see Igarashi 2017.

27 Ibn al-Furāt, Ta'rīkh al-duwal (1936-42), 435-436; Fischel 1956, 293-294; Fischel 1967, 79$80,164$.

28 Ibn al-Furāt, Ta'rīkh al-duwal (1936-42), 9: 365. On Ibn Duqmāq and his relations to Ibn alFurāt, see Massoud 2007, 28-38.

29 Massoud 2007, 29.

30 On him, see Massoud, "Ibn Hijjji”, $E P^{3}$.

31 Ibn Hijjīi, Ta'rīkh (2003), 726.

32 Ibn Qādị Shuhba, Ta'rīkh (1977-97), 195-196; see also Ibn Ḥajar al- 'Asqalānī, Inbā' al-ghumr (1967-76), 4: 246-247; Inbā’ al-ghumr (1969-98), 2: 150; al-Sakhāwī, al-Ḍaw' (1934-36), 1: 155156.

33 On al-'Aynī and his chronicles, see Nakamachi 2005; Marmon, “al-'Aynī, Badr al-Dīn”, $E P^{3}$. 
'Iqd al-jumān. ${ }^{34} \mathrm{He}$ mentions Ibn Khaldūn's birth year erroneously as $733 \mathrm{H}$, not $732 \mathrm{H}$, yet he follows Ibn Khaldūn's public career in the Maghrib, al-Andalus, and Egypt, and he does not forget to refer to Ibn Khaldūn's history consisting of seven volumes, as well as his meeting with Tìmūr (d. 807 H/1405 CE) in Damascus. At the end, al-'Aynī notes that Ibn Khaldūn was suspected of disgraceful matters (umūr qabīha), although what was meant by "disgraceful matters" is not entirely clear (see below).

Al-'Aynī’s rival, al-Maqrīzī (ca. 766-845 H/1364-1442 CE), ${ }^{35}$ provides some details about Ibn Khaldūn's life in his chronicle Kitāb al-Sulūk li-ma'rifat duwal al-mulūk. For instance, he tells that the Mamlūk amīr Alțunbughā al-Jūbānī (d. 792 H/1390 CE), ${ }^{36}$ with whom Ibn Khaldūn became acquainted soon after his arrival in Cairo, played a significant role in Ibn Khaldūn's success; but Ibn Khaldūn does not refer to his personal relationship with this amīr. ${ }^{37}$ Al-Maqrīzī also mentions briefly Ibn Khaldūn's meeting with Tīmūr and notes that some of those captured by the Tīmūrid army in Damascus were emancipated through Ibn Khaldūn's mediation. ${ }^{38}$ In general, however, al-Maqrīzì devotes surprisingly few words to his master in his chronicle. The necrology of Ibn Khaldūn in it is strikingly brief, occupying just two and half lines in the printed text. ${ }^{39}$

By contrast, al-Maqrīzì devotes many pages to Ibn Khaldūn in the biographical dictionary of his contemporaries, Durar al- $u q u \bar{u} .{ }^{40}$ While his main sources were Ibn al-Khațīb's Iḥāṭa and Ibn Khaldūn's Ta'rîf, al-Maqrīzī adds some details in his own work. For instance, he gives a more detailed account about Ibn Khaldūn's relationship with the amīr Alțunbughā al-Jūbānī in Durar al-'uqūd than in the Sulūk. According to al-Maqrīzī, the amīr introduced Ibn Khaldūn to the sultan Barqūq, who then appointed Ibn Khaldūn as professor at al-Madrasa alQamhiyya in al-Fusțāț..1 Al-Maqrīzī also states that Ibn Khaldūn was in alHanbūshiyya in al-Fayyūm, Middle Egypt, a waqf (endowment) property for al-

34 Al-'Aynī, 'Iqd al-jumān, MS Ahmet III 2911/a19, fols. 81v-82r; see also Badawī 1962, 287-288.

35 On him, see Bauden 2014. On al-Maqrīzī's relations to Ibn Khaldūn, see Irwin 2003.

36 On this amīr, see Ibn Ḥajar al-'Asqalānī, Inbā' al-ghumr (1967-76), 3: 38; Inbā' al-ghumr (1969-98), 1: 404; Ibn Taghrībirdī, al-Manhal (1984-2009), 3: 57-61; Ibn Taghrībirdī, al-Nujūm (1929-72), 12: 120.

37 Al-Maqrīzī, al-Sulūk (1934-73), 3: 480, 517; Fischel 1956, 297-299.

38 Al-Maqrīzì, al-Sulūk (1934-73), 3: 1052, 1056; see also Badawī 1962, 310.

39 Al-Maqrīīi, al-Sulūk (1934-73), 4: 24.

40 Al-Maqrīzī, Durar al-'uqūd (2002), 2: 383-410. Before Maḥmūd al-Jalīlī published the entire manuscript of Durar al-'uqūd that was in his private collection, he edited the biography of Ibn Khaldūn included in his manuscript. See al-Jalīlī 1966.

41 Al-Maqrīzī, Durar al- 'uqūd (2002), 2: 395. 
Madrasa al-Qamhiyya, when he was summoned to be appointed the Mālikī chief judge in Cairo for the second time..$^{42}$ In the Ta'riff, Ibn Khaldūn himself recounts that he stayed in al-Fayyūm at that time to collect his harvest (li-damm zar $\bar{\imath}) .{ }^{43}$ Thus, he directly obtained his salary and ration for professorship at this madrasa from the waqf property, although it seems to have been uncommon; usually, the administrative members of an institution collected the harvest and distributed it among the staff. In any case, al-Maqrīzī praises Ibn Khaldūn's 'Ibar, particularly its Muqaddima, so highly that he describes it as "the cream of knowledge and learning" (zubdat al-ma'ârif wa-l-'ulūm) and "the outcome of good insight and intelligence" (natījat al-'uqūl al-salīma wa-l-fuhūm). ${ }^{44}$ Moreover, he mentions approximately twenty anecdotes at the end of the biography, beginning each with the phrase "Ibn Khaldūn told us" (haddathanā [or akhbaranā] Abū Zayd). For example, Ibn Khaldūn reported that he heard from the Nașrid ruler Muhammad V (r. 755-760 H/1354-1359 CE, 763-793 H/1362-1391 CE) that Pedro I of Castile (r. 1350-1369) was killed by his half-brother in their grapple during peace negotiations. ${ }^{45}$ In the biography of Pedro in Durar al- 'uqūd, al-Maqrīzī refers to this story of Pedro's death, while he also mentions another version, according to which Pedro was arrested and executed. ${ }^{46}$ In the 'Ibar, which was al-Maqrīzì's main source for the biography of Pedro, Ibn Khaldūn wrote the latter version only. ${ }^{47}$ The Egyptian encyclopedist al-Qalqashandi (756-821 H/1355-1418 CE), who often cites the 'Ibar in his work, also does not refer to this account; rather, he merely mentions that Pedro's brother defeated Pedro and killed him. ${ }^{48}$ Thus, it seems that al-Maqrīzī heard most, if not all, of the anecdotes that he collected at the end of the biography of Ibn Khaldūn orally from Ibn Khaldūn. Overall, al-Maqrīzī relied heavily on Ibn Khaldūn in Durar al- 'uqūd. ${ }^{49}$

Ibn Hajar al-'Asqalānī (773-852 H/1372-1449 CE), ${ }^{50}$ the Egyptian hadìth scholar and jurist, wrote biographies of Ibn Khaldūn in some of his works. For

42 Al-Maqrīīì, Durar al- 'uqūd (2002), 2: 396.

43 Ibn Khaldūn, al-Ta'rîf (1951), 347.

44 Al-Maqrīīì, Durar al-'uqūd (2002), 2: 403.

45 Al-Maqrīzì, Durar al-'uqūd (2002), 2: 404-405.

46 Al-Maqrīzì, Durar al- 'uqūd (2002), 1: 482-486. Mayte Penelas’ paper "al-Maqrīzī and Christian Spain", presented at the conference "The Maghrib in the Mashriq", dealt with this issue, on which she is preparing an article.

47 Ibn Khaldūn, al-'Ibar (1956-60), 4: 377-378, 394; 7: 679-680.

48 Al-Qalqashandī, Șubh al-a'shā (1913-19), 5: 269; cf. Ibn Khaldūn, al-'Ibar (1956-60), 4: 394. On al-Qalqashandī, see Bosworth, “al-Ḳalḳashandī”, $E I^{2}$; Berkel 2009.

49 See Ito 2015.

50 On him, see Rosenthal, “Ibn Ḥadjar al-'Asḳalānī”, $E I^{2}$. 
Ibn Khaldūn's necrology in his chronicle Inbā' al-ghumr, Ibn Hajar relied on al'Aynī's 'Iqd al-jumān, for the most part. ${ }^{51}$ Consequently, he repeated al-'Aynī's mistake in Ibn Khaldūn's birth year, although he obtained an ijāza (license) from Ibn Khaldūn, in which the latter dated his own birthday explicitly as 1 Ramaḍān 732 (27 May 1332). ${ }^{52}$ Along with 'Iqd al-jumān, Ibn Ḥajar consulted Ibn al-Khațîb’s Inạta but erroneously stated the name of Khaldūn's son as 'Abd al-Rahịm, not 'Abd al-Rahmān. On other occasions, Ibn Hajar gives some details about Ibn Khaldūn's life in Egypt. For example, we learn from this chronicle that Ibn Khaldūn's two sons, Muhammad and 'Alī, survived a shipwreck in Alexandria in $786 \mathrm{H} / 1384 \mathrm{CE}$, while his five daughters drowned..$^{53}$ About this incident, Ibn Khaldūn merely mentions in his autobiography that he lost his family, children, and possessions while travelling from Tunis to Cairo because of a storm. ${ }^{54}$ Moreover, Ibn Hajar cites the Mamlūk sultan Barqūq's comment on Tīmūr and the Ottomans, and adds that he heard Ibn Khaldūn saying repeatedly that "there is nothing more fearful for the ruler of Egypt than the Ottomans"; ${ }^{55}$ however, for this episode Ibn Hajar seems to have relied on al-Maqrīzī, who transmits Barqūq's comment from an amīr, without referring to Ibn Khaldūn. ${ }^{56}$ It is not clear why Ibn Hajar attributed Barqūq's comment on the Ottomans to Ibn Khaldūn. As Ibn Hajar says, he may have heard it from Ibn Khaldūn, who told it as if it had been his own statement; or Ibn Hajar may have confused al-Maqrīzī with Ibn Khaldūn as his source; or he may have indicated Ibn Khaldūn's prescience here, as Robert Irwin points out. ${ }^{57}$

Ibn Hajar's biography of Ibn Khaldūn in the supplement to his own biographical dictionary, Dhayl al-Durar al-kâmina, is almost the same as the necrology in Inb $\bar{a}^{\prime}$ al-ghumr. ${ }^{58}$ However, the account in his biographical dictionary of the judges in Egypt, $R a f^{\prime}$ al-ișr, is different and more detailed. ${ }^{59}$ The Raf' al-ișr was mainly based on the biographical dictionary of the Egyptian judges by Jamāl alDīn 'Abd Allāh b. Aḥmad al-Bishbīshī (762-820 H/1361-1417 CE), which appears

51 Ibn Ḥajar al-'Asqalānī, Inbā' al-ghumr (1967-76), 5: 327-332; Inbā' al-ghumr (1969-98), 2: 339-340; see also Badawī 1962, 285-287.

52 Ritter 1953, 83, plate XVII.

53 Ibn Ḥajar al-'Asqalānī, Inbä' al-ghumr (1967-76), 2: 163; Inbāa' al-ghumr (1969-98), 1: 291.

54 Ibn Khaldūn, al-Ta'rîf (1951), 259.

55 Ibn Ḥajar al-'Asqalānī, Inbä' al-ghumr (1967-76), 3: 247-248; Inbā' al-ghumr (1969-98), 1: 492; Irwin 2018, 106.

56 Al-Maqrīzì, Durar al- 'uqūd (2002), 1: 445.

57 Irwin 2018, 106.

58 Ibn Ḥajar al-'Asqalānī, Dhayl al-Durar (1992), 172-173.

59 Ibn Ḥajar al-'Asqalānī, Raf' al-iṣr (1998), 233-237; see also Badawī 1962, 279-285. 
to have been lost. ${ }^{60}$ For Ibn Khaldūn's biography, moreover, Ibn Hajar consulted al-Maqrīzì’s Durar al- 'uqūd and Ibn al-Khațīb’s Ihạța. In this biography, Ibn Hajar mentions Ibn Khaldūn's genealogy as in Ibn al-Khaṭīb’s Ihạța and dates his birthday correctly as 1 Ramadān $732 \mathrm{H}$. He gives the same information as that found in al-Maqrīzī's Durar al- 'uqūd - for example, Ibn Khaldūn was in al-Fayyūm because of his salary for the professorship at al-Madrasa al-Qamhiyya - as well as some unique information, based on al-Bishbīshì: for instance, Ibn Khaldūn later settled in a house by the Nile where "he delighted in the company of singing girls and young men and married a woman who had a mentally disturbed younger brother and the disgraceful things multiplied" (tabassața bi-l-sakan 'alä al-bahr wa-akthara min samā' al-muțibāt wa-mu'āsharat al-ahdāth wa-tazawwaja imra' a lahā akh amrad yunsab li-l-takhlit fa-kathurat al-shanā'a 'alayhi). ${ }^{61}$ What al-'Aynī meant by the similar words "disgraceful matters” (umūr qabīha) was probably the things that al-Bishbīshì and Ibn Hajar mentioned, as Ali Oumlil and Robert Irwin surmise. ${ }^{62}$ In any case, Ibn Khaldūn's biography in Raf' al-ișr includes many harsh words about him. ${ }^{63}$ This is at least partly due to al-Bishbīshì's critical view of Ibn Khaldūn; however, Ibn Hajar himself was also critical of Ibn Khaldūn in some cases, such as the fact that he stubbornly clung to a Maghribistyle clothing instead of adopting the Egyptian-style clothing of the judges. ${ }^{64}$ According to Ibn Hajar, al-Bishbīshī worked as deputy for al-Maqrīzī when the latter was the muhtasib (prefect of markets). ${ }^{65}$ Al-Maqrīzī praises al-Bishbīshì’s biographical dictionary of the judges and mentions that he associated with alBishbīshī for several years. ${ }^{66}$ Thus, it is not clear why al-Bishbīshī had an almost opposite view on Ibn Khaldūn from al-Maqrīzī.

60 On al-Bishbīshī, see al-Maqrīīị, Durar al-'uqūd (2002), 2: 357-358; Ibn Ḥajar al-'Asqalānī, Inbā' al-ghumr (1967-76), 7: 287; Inbā' al-ghumr (1969-98), 3: 149; al-Sakhāwī, al-Daw' (193436), 5: 7. On the relation of al-Bishbīshī’s work to Ibn Ḥajar's Raf' al-iṣr, see al-Sakhāwī, al-I' lān (1349/1930-1), 105-106; Rosenthal 1968, 428.

61 Ibn Ḥajar al-'Asqalānī, Raf' al-iṣr (1998), 236; Irwin 2018, 106; see also Fischel 1956, 291, n. 3. The English translation is based on Robert Irwin's.

62 Based on Oumlil 1962, 135-136, Robert Irwin mentions that al-'Aynī "implausibly accused Ibn Khaldūn of presiding over an immoral household and of being a homosexual” (Irwin 2018, 107). Oumlil's sources are Ibn Hajar's Raf' al-ișr and al-'Aynī's 'Iqd al-jumān. Neither of them, al'Aynī in particular, charged Ibn Khaldūn with the immorality and the homosexuality so explicitly as Oumlil and Irwin write.

63 See Morimoto 2002, 125-130, where further accounts in Ibn Ḥajar’s Raf' al-ișr are cited.

64 Ibn Ḥajar al-'Asqalānī, Raf' al-iṣr (1998), 235; Ibn Ḥajar al-'Asqalānī, Inbā' al-ghumr (196776), 5: 332; Inbā' al-ghumr (1969-98), 2: 340; Ibn Ḥajar al-'Asqalānī, Dhayl al-Durar (1992), 173.

65 Ibn Ḥajar al-'Asqalānī, Inbā' al-ghumr (1967-76), 7: 287; Inbā' al-ghumr (1969-98), 3: 149.

66 Al-Maqrīīi, Durar al-'uqūd (2002), 2: 357-358. 
In his Ta'rīkh, the Syrian jurist and historian Ibn Qāḍi Shuhba (779-851 H/ 1377-1448 CE) ${ }^{67}$ refers to some details about Ibn Khaldūn. Quoting Ibn Duqmāq's history, Ibn Qāọi Shuhba tells the anecdote that Ibn Duqmāq met a clever boy with Ibn Khaldūn, and he notes that according to Ibn Hajar al-'Asqalānī, this boy died young. ${ }^{68}$ Ibn Qāḍi Shuhba also reports Ibn Khaldūn's meeting with Tīmūr, citing an eyewitness account as a source. ${ }^{69}$ Concerning the shipwreck involving Ibn Khaldūn's family, Ibn Qāọī Shuhba's description is a little different than that of Ibn Hajar al-'Asqalānī. ${ }^{70}$ They may have quoted a same source (perhaps Ibn Duqmāq's history, although this cannot be substantiated) differently or they may have relied on different sources. Unfortunately, the published version of Ibn Qādī Shuhba's history, which is an abridged version, contains no necrology of Ibn Khaldūn; the manuscripts of Ibn Qāḍi Shuhba's historical works require further investigation. ${ }^{71}$

In the biography of the mystic thinker Muhyī al-Dīn Ibn al-'Arabī (560638 H/1165-1240 CE) in his biographical dictionary, al- 'Iqd al-thamīn, Taqī al-Dīn al-Fāsī (775-832 H/1373-1429 CE), the historian of Mecca, cites Ibn Khaldūn's opinion about Șūfism: Ibn Khaldūn distinguished between the early "orthodox" and later "heretical" Șūfism and criticized the latter, counting Ibn al-'Arabī among the advocates of the latter. ${ }^{72}$ In addition, al-Fāsī makes reference to Ibn Khaldūn's history on several occasions. ${ }^{73}$

His other biographical dictionary, Dhayl al-Taqyid, includes the biography of Ibn Khaldūn..$^{74}$ In this work, al-Fāsī names some of Ibn Khaldūn's teachers and states that Ibn Khaldūn learned the Șaḥị̣ of al-Bukhārī (d. 256 H/870 CE) from

67 On him, see Darwīsh 1994; Reisman 1998; Massoud 2007, 81-85, 142-146, 183-189.

68 Ibn Qāḍi Shuhba, Ta'rīkh (1977-97), 1: 130-131.

69 Ibn Qāọī Shuhba, Ta'rīkh (1977-97), 4: 182.

70 Ibn Qāḍī Shuhba, Ta'rīkh (1977-97), 1: 138; cf. Ibn Ḥajar al-'Asqalānī, Inbā' al-ghumr (196776), 2: 163; Inbä' al-ghumr (1969-98), 1: 291.

71 On the state of the art of the historiographical studies on Ibn Qādị Shuhba, see Reisman 1998; Massoud 2007, esp. 81-85, 142-146, 183-189.

72 Al-Fāsī, al- 'Iqd (1958-69), 2: 178-181; Knysh 1999, 191-192. Allen James Fromherz has expressed doubt about the reliability of this report (Fromherz 2010, 126-127). However, Ibn Khaldūn's opinion cited by al-Fāsī "is consistent with what is found in the Muqaddima", as Robert Irwin argues (Irwin 2018, 115-117, also 195-196). In addition, Fromherz does not seem to have examined al-Fāsī and mentions him erroneously as "a scholar from Fez who claimed to have met Ibn Khaldun in Egypt” (Fromherz 2010, 126). On al-Fāsī, see Rosenthal, “al-Fāsī”, $E I^{2}$. Although his family stemmed from Fez (therefore, the attributive [nisba] "al-Fāsī”), Taqī al-Dīn al-Fāsī was born in Mecca and studied with Ibn Khaldūn probably in Egypt.

73 Al-Fāsī, al- Iqd (1958-69), 1: 441, 443-444, 465; see also Rosenthal 1967, lxvi, n. 80.

74 Al-Fāsī, Dhayl al-Taqyīd (1990-97), 2: 513. 
Abū al-Barakāt al-Balafīqī (680-771 H/1281-2-1370 CE). ${ }^{75}$ According to Ibn Ḥajar al-'Asqalānī, Ibn Khaldūn had great respect for al-Balafīqī. ${ }^{76}$ In his autobiography, however, Ibn Khaldūn simply mentions that he learned from al-Balafiqi al-Muwatța' of Mālik b. Anas (d. 179 H/796 CE), without referring to the Șahịh of al-Bukhārī. ${ }^{77}$ Based on Ibn Khaldūn's own writing (bi-khațtihi), the Egyptian hadìth scholar al-Sakhāwī (see below), lists the same teachers of Ibn Khaldūn as al-Fāsī does. ${ }^{78}$ Therefore, it is assumed that al-Fāsī and al-Sakhāwī used a writing of Ibn Khaldūn (ijāza?), and not his autobiography, as their source of information. Moreover, from Dhayl al-Taqyīd, we learn that Ibn Khaldūn gave an ijāza not only to Ibn Ḥajar al-'Asqalānī but also to Abū al-Fatḥ b. Abī Bakr b. al-Ḥusayn al-Marāghī (775-859 H/1374-1455 CE); ${ }^{79}$ I could find no information about alMarāghī's relation to Ibn Khaldūn in the other sources I consulted..$^{80}$

\section{Later authors in the Mashriq}

Many references to Ibn Khaldūn continue to be found in Egypt and Syria in the 9th-10th/15th-16th centuries. These references were based on earlier accounts.

Ibn 'Arabshāh (791-854 H/1389-1450 CE) was born in Damascus, captured, and carried with his family to Samarqand by the Tīmūrid army. ${ }^{81} \mathrm{He}$ later returned to the Mamlūk sultanate, where he wrote his famous Arabic biography of Tīmūr. In it, Ibn 'Arabshāh gives two accounts of Ibn Khaldūn's meeting with Tīmūr. The source for one of them seems to have been an eyewitness account. ${ }^{82}$ The other

75 On Abū al-Barakāt Muḥammad b. Muḥammad b. Ibrāhīm al-Balafĩqī, see Puente 2012; Puente, "al-Balafìqī", $E I^{3}$. In the edition of Dhayl al-Taqyīd, his nisba is spelt erroneously as alBulqīnī; moreover, Ibn Khaldūn's teacher of the Qur'ānic sciences was not Ibn Nizāl (?) but Ibn Burrāl (see Ibn Khaldūn, al-Ta'rīf [1951], 15-17, 309-310).

76 Ibn Ḥajar al-'Asqalānī, al-Durar (1993), 4: 157 (biography of al-Balafìqī). See also Rosenthal 1967, xlii.

77 Ibn Khaldūn, al-Ta'rîf (1951), 305.

78 Al-Sakhāwī, al-Daw' (1934-36), 4: 145.

79 On Abū al-Fath Muhammad b. Abī Bakr b. al-Ḥusayn al-Marāghī, see al-Sakhāwī, al-Ḍaw' (1934-36), 7: 162-165.

80 It is possible that this information was added later by the copyist of a manuscript of Dhayl alTaqyīd. See al-Fāsī, Dhayl al-Taqyīd (1990-97), 2: 513, n. 4; see also the editor's introduction to Dhayl al-Taqyīd (1990-97), 1: 25-29.

81 On him, see McChesney 2006.

82 Ibn 'Arabshāh, 'Ajā’ib al-maqdūr (1986), 252-255; see also Badawī 1962, 306-308. 
account was presumably based on hearsay knowledge of Ibn Khaldūn's autobiography, since Ibn 'Arabshāh recounts that he heard about Ibn Khaldūn's history but did not read it. ${ }^{83}$

In his biographical dictionary, al-Manhal al-șāfì, the Egyptian historian Ibn Taghrībirdī (ca. 812-874 H/1409-10-1470 CE) apparently relied on Durar al-'uqūd of his master al-Maqrīzī, as is often the case with his work. ${ }^{84}$ His obituary notice of Ibn Khaldūn in his chronicle, al-Nujūm al-zāhira, was based on al-Maqrīzī's Sulūk and Durar al- 'uqūd. ${ }^{85}$ On other occasions in this chronicle, Ibn Taghrībirdī makes fewer references to Ibn Khaldūn than al-Maqrīzī does in the Sulūk.

As the Egyptian copyist, money-changer, and historian Ibn al-Ṣayrafī (819ca. $900 \mathrm{H} / 1416-1494 \mathrm{CE}$ ) himself reveals, the source for the necrology of Ibn Khaldūn in his chronicle Nuzhat al-nufūs was al-'Aynī's 'Iqd al-jumān, on which he relied generally for the later years. ${ }^{86}$ On other occasions concerning Ibn Khaldūn as well, Ibn al-Ṣayrafī seems to have borrowed from 'Iqd al-jumān. For example, Ibn al-Ṣayrafi mentions that a robe of honor was given to Ibn Khaldūn for the confirmation of his post as chief judge at the end of the year $801 \mathrm{H} / 1399 \mathrm{CE}$, which is found only in al-'Aynī's 'Iqd al-jumān. ${ }^{87} \mathrm{Ibn}$ al-Ṣayrafì also states that the sultan al-Nāṣir Faraj (r. 801-808 H/1399-1405 CE, 808-815 H/1405-1412 CE) married the daughter of the amīr Balāṭ al-Sa 'dī in $803 \mathrm{H} / 1401 \mathrm{CE}$ and that Ibn Khaldūn did not attend their wedding ceremony; again, al-'Aynī is the sole reference for this incident. $^{88}$

In his biographical dictionary, al-Daw' al-lāmi', al-Sakhāwī (831-902 H/14278-1497 CE) ${ }^{89}$ relied mainly on the works of his master Ibn Hajar al-'Asqalānī, $R a f^{\text {c }}$ al-iṣr and Inbā' al-ghumr. ${ }^{90}$ Thus, he named Khaldūn's son erroneously as 'Abd al-Rahịm, not 'Abd al-Raḥmān, as Ibn Ḥajar did in his Inbā' al-ghumr (see above), although al-Sakhāwī also consulted al-Maqrīzì's Durar al-'uqūd. Moreover, al-

83 Ibn 'Arabshāh, 'Ajā’ib al-maqdūr (1986), 452-454.

84 Ibn Taghrībirdī, al-Manhal (1984-2009), 7: 205-209; see also Badawī 1962, 288-291. On Ibn

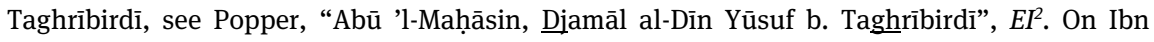
Taghrībirdī’s reliance in his Manhal on al-Maqrīzì's Durar al- 'uqūd, see Ito 2015, 321-322.

85 Ibn Taghrībirdī, al-Nujūm (1929-72), 13: 155-156.

86 Ibn al-Ṣayrafì, Nuzhat al-nufūs (1970-94), 2: 221. On Ibn al-Ṣayrafĩ and his sources, see Massoud 2007, 133-136, 175-176.

87 Ibn al-Ṣayrafī, Nuzhat al-nufūs (1970-94), 2: 20; cf. al-'Aynī, 'Iqd al-jumān, MS Ahmet III 2911/a19, fol. 26r.

88 Ibn al-Ṣayrafī, Nuzhat al-nufūs (1970-94), 2: 114; cf. al-'Aynī, 'Iqd al-jumān, MS Ahmet III 2911/a19, fol. 53v.

89 On him, see Petry, “al-Sakhāwī”, $E I^{2}$.

90 Al-Sakhāwī, al-Ḍaw' (1934-36), 4: 145-149; see also Badawī 1962, 292-299. 
Sakhāwī quoted some comments about Ibn Khaldūn by the latter's contemporaries such as Ibn 'Ammār (768-844 H/1367-1441 CE). ${ }^{91}$ Further data on Ibn Khaldūn's activities and personal relations are to be found scattered in this work, as Franz Rosenthal has shown. ${ }^{92}$ In the I'lān, his treatise on the historiography, alSakhāwī gives the same accounts as those found in the Daw' concerning the 'Ibar and the Muqaddima, while he mentions only in the former work that a copy of the 'Ibar was in the Bāsițiyya library in Cairo. ${ }^{93}$

In his chronicle Nayl al-amal, the Egyptian historian 'Abd al-Bāsit b. Khalīl al-Malați (844-920 H/1440-1514 CE) seems to have derived the necrology of Ibn Khaldūn from Ibn Ḥajar al-'Asqalānī's Inbā' al-ghumr and possibly also al-'Aynī's 'Iqd al-jumān, but he made mistakes. For example, the attributive (nisba) "alQurashī” is included in Ibn Khaldūn's genealogy; also, Ibn Khaldūn's birth year should be $733 \mathrm{H}$, according to Ibn Hajar and al-'Aynī, not $736 \mathrm{H}$ as given by 'Abd al-Bāsiṭ. ${ }^{94}$

The Egyptian jurist and polymath al-Suyūṭī (849-911 H/1445-1505 CE) presumably relied on Ibn Hajar al- 'Asqalānì's Inbā' al-ghumr for the biography of Ibn Khaldūn. ${ }^{95}$ The last Mamlūk Egyptian chronicler, Ibn Iyās (852-ca. 930 H/1448$1524 \mathrm{CE}$ ), borrowed the necrology of Ibn Khaldūn from al-Maqrīzī's Sulūk and 'Abd al-Bāsiṭ al-Malațī's Nayl al-amal, and he repeated the mistakes of the latter. ${ }^{96}$ The sources of the Syrian scholar and prosopographer Ibn al- Imād al-Hanbali (1032-1089 H/1623-1679 CE) for the biography of Ibn Khaldūn were Ibn Hajar al'Asqalānī's Inbā' al-ghumr and Ibn Taghrībirdī’s Manhal. ${ }^{97}$

91 On him, see al-Sakhāwī, al-Ḍaw' (1934-36), 8: 232-234. Ibn 'Ammār studied part of the Muqaddima with Ibn Khaldūn (al-Sakhāwī, al-Ḍaw' [1934-36], 8: 233; Rosenthal 1968, 44).

92 Rosenthal 2000.

93 Al-Sakhāwī, al-I' lān (1349/1930-1), 71, 94-95, 151; Rosenthal 1968, 370, 407, 497-498; see also Badawī 1962, 299-301; cf. al-Sakhāwī, al-Ḍaw' (1934-36), 4: 147. On al-Madrasa al-Bāsiṭiyya or al-Jāmi' al-Bāsiṭi and its founder Zayn al-Dīn 'Abd al-Bāsiṭ b. Khalīl (784-854 H/1382-31451 CE), see al-Maqrīzī, al-Khițaț (2002-2004), 4: 351-354; al-Khițaṭ (1853), 2: 331; Igarashi 2013. 94 'Abd al-Bāsiț, Nayl al-amal (2002), 3: 133-134. On 'Abd al-Bāsiț, see Massoud 2007, 67-69. 95 Al-Suyūṭi, Husn al-muhâậara (1967-68), 1: 462. On al-Suyūṭī, see Spevack 2009.

96 Ibn Iyās, Badā'i al-zuhūr (1960-75), 1/2: 754. On Ibn Iyās, see Brinner, “Ibn Iyās”, EI²; Massoud 2007, 69-76.

97 Ibn al-'Imād al-Ḥanbalī, Shadharāt al-dhahab (1931-32), 7: 76-77. On Ibn al-'Imād al-Ḥanbalī, see Rosenthal, "Ibn al-'Imād”, $E I^{2}$. 


\section{Later authors in the Maghrib and al-Andalus}

In contrast to the Mashriq, Ibn Khaldūn was not often referred to in the Maghrib and al-Andalus in the 9th-10th/15th-16th centuries, which was also the case in the preceding century. According to Mohamed B. A. Benchekroun, the Moroccan scholar Ya'qūb b. Mūsā (or 'Abd Allāh) al-Saytānī (?) criticized Ibn Khaldūn's Muqaddima in his commentary of the didactic poetry of the inheritance laws (farā'id $).{ }^{98}$ The Andalusi judge and jurist Ibn al-Azraq (d. 896 H/1491 CE) based his treatise on politics Badā'i' al-silk fi tabā'i' al-mulk on the Muqaddima, which Aḥmad Bābā al-Tinbuktī (see below) pointed out. ${ }^{99}$ Ibn Khaldūn's early writing on Șüfism, Shifä' al-sā'il li-tahdhīb al-masā'il, continued to be mentioned by the Maghribi scholar and Ṣūfĩ Aḥmad Zarrūq (846-899 H/1442-1494 CE) and others until the early 19 th century CE. ${ }^{100}$

As for biographical notices, the Moroccan polygraph Ibn al-Qāḍī al-Miknāsī (960-1025 H/1553-1616 CE) ${ }^{101}$ includes Ibn Khaldūn in his biographical dictionary of the prominent persons of Fez. ${ }^{102}$ It is an abridgment of Ibn Khadūn's biography in Ibn al-Khațīb’s Iḥạta, although Ibn al-Qāọi al-Miknāsī adds that Ibn Khaldūn died in $808 \mathrm{H} / 1405-6 \mathrm{CE}$.

The West African jurist and biographer Aḥmad Bābā al-Tinbuktī (9631036 H/1556-1627 CE) ${ }^{103}$ consulted Ibn al-Khațīb’s Iḥāta and al-Sakhāwī’s Ḍaw'

98 Benchekroun 1974, 357; see also Cheddadi, “Ibn Khaldūn”, $E I^{3}$. Benchekroun reads the nisba of the author as al-Sītānī and calls the title of his work Muntahā al-bānī wa-murtaqā al-ma 'ānī. Carl Brockelmann reads the nisba as al-Bustānī (or al-Sabtānī) and calls the title of the work Muntahā al-qānī wa-murtaqã al-ma 'ānī (Brockelmann 1996, S1: 666). On Ya'qūb b. 'Abd Allāh alSaytānī, see further Ibn al-Qāḍī al-Miknāsī, Jadhwat al-iqtibās (1973), 558; Aḥmad Bābā al-Tinbuktī, Nayl al-ibtihāj (1989), 621. He flourished presumably in the first half of the 9th/15th century as his disciple 'Abd al-Raḥmān al-Kāwānī is said to have died in 860 H/1455-6 (Ibn al-Qāḍi al-Miknāsī, Jadhwat al-iqtibās [1973], 404).

99 Aḥmad Bābā al-Tinbuktī, Nayl al-ibtihāj (1989), 561. On Ibn al-Azraq, Muhạmmad b. 'Alī b. Muḥammad, and his relations to Ibn Khaldūn, see further al-Sakhāwī, al-Ḍaw' (1934-36), 9: 2021; al-Maqqarī, Nafh al-țīb (1968), 2: 699-704; Isahak 2010; Delgado Pérez 2009; Benchekroun 1974, 356-357; al-Azmeh 1982, 146, 156-158; Abdesselem 1983, 17-37; Simon 2002, 19-21; Cheddadi 2002, xl; Alatas 2013, 102-103; Irwin 2018, 162.

100 Cheddadi 2002, xxii; Özer 2017, xxvi. On Aḥmad b. Aḥmad b. Muhammad Zarrūq al-Burnusī, see al-Sakhāwī, al-Ḍaw' (1934-36), 1: 222-223; Ibn al-Qāḍī al-Miknāsī, Jadhwat al-iqtibās (1973), 128-131; Aḥmad Bābā al-Tinbuktī, Nayl al-ibtihāj (1989), 130-134; Brockelmann 1996, 2: 253-254; Brockelmann 1996, S2: 360-362; Kugle, “Zarrūq, Aḥmad”, $E I^{3}$.

101 On him, see Deverdun, "Ibn al-Ḳāịī”, $E I^{2}$.

102 Ibn al-Qāḍī al-Miknāsī, Jadhwat al-iqtibās (1973), 410-413; see also Badawī 1962, 301-303.

103 On him, see de Moraes Farias, “Aḥmad Bābā al-Tinbuktī”, $E P^{3}$. 
without specifying the latter in his biographical dictionary. ${ }^{104} \mathrm{He}$ also refers to Ibn Khaldūn's autobiography but merely mentions that Ibn Khaldūn had troubles with Ibn 'Arafa and his followers in Tunis.

Al-Maqqarī (ca. 986-1041 H/1577-1632 CE) was born in Tlemcen, was active in Morocco, and later left Fez for Egypt and Syria, where he compiled the history of al-Andalus, Nafh al-tịb. ${ }^{105}$ Thus it may be not appropriate that he is counted as an author in the Maghrib. In any case, al-Maqqari inserts the biography of Ibn Khaldūn into the Nafh al-tī $b^{106}$ In this instance, his biography is largely a citation of Ibn al-Khațīb's Ihāța; however, he adds that Ibn Khaldūn was sent as envoy from Granada to Pedro I of Castile. ${ }^{107}$ Concerning Ibn Khaldūn's later life in Cairo, he quotes a note by Ibrāhīm b. Ahmmad al-Bā'ūnī (777-870 H/1376-1465 CE), member of a prominent Syrian family, ${ }^{108}$ who had mistakenly written that Ibn Khaldūn died in $807 \mathrm{H}$, not $808 \mathrm{H}$. Al-Maqqari also recounts that he saw the eight-volume copy of Ibn Khaldūn's history, the 'Ibar, which contained a note in Ibn Khaldūn's own hand. Indeed, al-Maqqarī often cites the 'Ibar in his Nafh al-țīb.

\section{Concluding remarks}

First, we have confirmed the importance of the external Arabic sources which Walter Fischel pointed out. They provide additional data on Ibn Khaldūn's life and activities, which are not found in his autobiography. We learn from them, for example, that he had a concubine in Granada; that he had at least two sons, Muhammad and 'Alī, and five daughters; that he married again in Cairo; and that he sometimes went to the countryside to collect the harvest.

We can also gain knowledge from these external sources about the contemporary views on Ibn Khaldūn. On the one hand, most of his contemporaries and near-contemporaries praised his talent and ability. His 'Ibar was well known and often cited, although the real worth of it, particularly that of its Muqaddima, "was not fully recognised in the Muslim world until the late nineteenth century" ${ }^{109} \mathrm{Be}-$ side al-Maqrīzī, al-Fāsī, Ibn al-Azraq, and al-Maqqarī, al-Qalqashandī should be

104 Aḥmad Bābā al-Tinbuktī, Nayl al-ibtihāj (1989), 250-252; see also Badawī 1962, 303-306.

105 On him, see Lévi-Provençal/Pellat, "al-Makkkarī”; Fierro/Molina 2009.

106 Al-Maqqarī, Naf̣̣ al-ṭīb (1968), 6: 171-192; see also Badawī 1962, 253-272.

107 Al-Maqqarī, Nafḥ al-țīb (1968), 6: 191.

108 On him, see al-Sakhāwī, al-Ḍaw' (1934-36), 1: 26-29. On the al-Bā'ūnī family, see Frenkel, "al-Bā'ūnì”, $E P^{3}$.

109 Cheddadi, “Ibn Khaldūn”, $E P$. 
added to those who made considerable use of the 'Ibar. ${ }^{110}$ On the other hand, some of his contemporaries criticized Ibn Khaldūn as too ambitious and stubborn, which apparently indicates an aspect of his personality.

Second, we have examined the relations between the external sources. On the whole, authors in the Maghrib and al-Andalus relied mainly on works written in the West, whereas authors in the Mashriq relied on works written in the East.

However, to what extent did this really reflect the intellectual network or communication of that time? We can assume some human, material, and informational exchanges between the West and the East. Every year, many Muslims from the West went through Egypt and Syria to Mecca for the hajj, and a number of scholars and Șūfîs travelled over lands in search for teachers, masters, colleagues, libraries, assemblies, and jobs. As for material exchanges, Ibn al-Khațib sent copies of his Ihạt $a$ and other works to Cairo to be placed as a waqf (donation) at the Khānqāh Sa'īd al-su'adā'. ${ }^{111}$ Later, the Maghribi ḥadīth scholar, preacher, and statesman Ibn Marzūq (d. 781 H/1379 CE) added a note to this manuscript of the Ihạța, after he moved to Cairo. ${ }^{112}$ Ibn al-Khaṭīb's son 'Alī also made additions to it when he visited Cairo. ${ }^{113}$ Moreover, al-Maqqarī found in it the reading notes of al-Maqrīzī and al-Suyūṭī, among others. ${ }^{114}$ When Ibn Marzūq's grandson visited Cairo, Ibn Ḥajar al-'Asqalānī gave him a manuscript that his grandfather had written in Cairo. ${ }^{115}$ Furthermore, there were lively letter exchanges among intellectuals. Ibn Khaldūn himself had a great deal of correspondence with Ibn alKhațib. ${ }^{116}$ Finally, we should not forget that the intellectual network extended across not only political but also religious boundaries. The Jewish physician and astronomer Ibn Zarzar, for example, was acquainted with Ibn Khaldūn and praised him before Pedro I of Castile when Ibn Khaldūn visited Seville for a diplomatic mission. ${ }^{117}$

Hence, should we suppose that it depends on the genre? As Ibn Khaldūn himself states,

110 See Björgman 1928, 83.

111 Ibn Khaldūn, al-Ta'rīf (1951), 121; al-Maqqarī, Nafḥ al-țīb (1968), 7: 105.

112 Ibn Ḥajar al-'Asqalānī, al-Durar (1993), 3: 362. On Ibn Marzūq, Shams al-Dīn Abū 'Abd Allāh Muḥammad b. Aḥmad b. Muḥammad, see Hadj-Sadok, “Ibn Marzūḳ”, EI' Peláez Rovira 2006.

113 Al-Maqqarī, Nafth al-țīb (1968), 7: 301-302.

114 Al-Maqqarī, Nafh al-țīb (1968), 7: 106.

115 Ibn Ḥajar al-'Asqalānī, al-Durar (1993), 3: 362.

116 See Fromherz 2014.

117 Ibn Khaldūn, al-Ta'rîf (1951), 85. 
Some later historians [...] showed a tendency toward greater restriction [...] They brought together the happenings of their own period and gave exhaustive historical information about their own part of the world. They restricted themselves to the history of their own dynasties and cities. ${ }^{118}$

Thus, there was certainly a gap, more or less, in the historiography of the western and eastern Arab world. ${ }^{119}$ However, how deep was this gap, in comparison with the gap between the Arab world and the "Persianate societies" or the "Persianate world" stretching east and north of Iraq to include Iran, Central Asia, and India, which formed distinctive Persianate cultural traditions, particularly in the Mongol and post-Mongol periods? It seems that Ibn Khaldūn came to be known in the Persianate world only much later because premodern Persian historiography paid little attention to the regions west of Iraq. ${ }^{120}$ In addition, what were the other disciplines such as jurisprudence, hadith studies, Șūfism, philosophy, medicine, and astronomy like? To answer these questions, further research is required on how wide and dense an intellectual network or communication in the Islamic or Islamicate world in the post-classical period from the 12th century CE through to the early 16th century CE could have been, while taking into account the differences in genres and individuals. ${ }^{121}$

118 Ibn Khaldūn, al-'Ibar (1956-60), 1: 4; Ibn Khaldūn, al-Muqaddima (1967), 1: 8. The English translation is Franz Rosenthal's.

119 However, it is noteworthy that al-Maqrīzì's Durar al- 'uqūd includes the biographies of many "foreigners", as Joseph Drory points out. I would like to thank Professor Drory for being generous and showing me his paper "Foreign Rulers in al-Maqrīzīs Biographical Dictionary Durar al'Uqūd", which was presented in May 2013 in the 22nd International Colloquium on the History of Egypt and Syria in the Fāțimid, Ayyūbid and Mamlūk Eras at Ghent University, Belgium, which I did not attend. Al-Maqrīzī may have attempted to write a kind of world history, keeping in mind Ibn Khaldūn's statement quoted above. Whatever the case may be, Durar al- 'uqūd deserves further investigation. I am preparing a paper on "Africans" in this biographical dicitonary. 120 The Tīmūrid Persian historiography did not refer to Tīmūr's meeting with Ibn Khaldūn (Fischel 1952, 4). The Urdu and the Persian translations of Ibn Khaldūn's Muqaddima were published respectively in 1924-1932 and in 1957-1959 (Fischel 1967, 9). It should be explored when Ibn Khaldūn became first known in Iran.

121 In this context, the concept of "Islamic (or Islamicate) republic of letters" should also be revisited. Muhsin J. al-Musawi recently provided several impressive examples that attest to this concept (al-Musawi 2015). However, was such an Islamic consciousness really as pervasive in every genre as he argues? For an overview of the cultural connections over time, see Romanov 2017. 


\section{Bibliography}

\section{Primary sources}

'Abd al-Bāsiț b. Khalīl al-Malațī (2002), Nayl al-amal fĩ dhayl al-duwal, ed. by 'Umar 'Abd alSalām Tadmurī, 9 vols., Sidon - Beirut: al-Maktaba al-'Așriyya.

Aḥmad Bābā al-Tinbuktī (1989), Nayl al-ibtihāj bi-tațrīz al-Dībāj, ed. by 'Abd al-Ḥamīd 'Abd Allāh al-Harrāma, Tripoli (Libya): Kulliyyat al-Da'wa al-Islāmiyya.

Al-'Aynī, Iqd al-jumān fí ta'rīkh ahl al-zamān, Topkapı Sarayı Müzesi Kütüphanesi MS Ahmet III 2911/a19.

Al-Fāsī, Taqī al-Dīn Muḥammad b. Aḥmad (1990-1997), Dhayl al-Taqyīd li-márifat ruwāt alsunan wa-l-masānīd, ed. by Muḥammad Șālị̣ b. 'Abd al-'Azīz al-Murād, 3 vols., Mecca: Jāmi'at Umm al-Qurā.

Al-Fāsī, Taqī al-Dīn Muḥammad b. Aḥmad (1958-1969), al-'lqd al-thamīn fĩ ta'rīkh al-balad alamīn, ed. by Fu'ād Sayyid et al., 8 vols., Cairo: Mațba'at al-Sunna al-Muhammadiyya (repr. Beirut: Mu'assasat al-Risāla, 1985-1986).

Ibn al-Aḥmar, Abū al-Walīd Yūsuf b. Muḥammad (1976), Alām al-Maghrib wa-l-Andalus: wahuwa Nathīr al-jumān fĩ shi'r man naẓamanī wa-iyyāhu al-zamān, ed. by Muḥammad Riḍwān al-Dāya, Beirut: Mu'assasat al-Risāla.

Ibn al-Aḥmar, Abū al-Walīd Yūsuf b. Muḥammad (1964), Kitāb Mustawdi' al-'alāma wamustabdi' al-'allāma, ed. by Muḥammad al-Turkī al-Tūnisĩ and Muḥammad b. Tāwīt al-Ṭitwānī, Rabat: Kulliyyat al-Ādāb wa-l-'Ulūm al-Insāniyya, Jāmi'at Muḥammad V.

Ibn 'Arabshāh (1986), 'Ajāìb al-maqdūr fĩ nawāìb Timmūr, ed. by Aḥmad Fā'iz al-Ḥimṣī, Beirut: Mu'assasat al-Risāla.

Ibn al-Furāt (1936-1942), Ta'rīkh al-duwal wa-l-mulūk, ed. by Costi K. Zurayk and Nejla Izzeddin, vols. 7-9, Beirut: The American University of Beirut.

Ibn Ḥajar al-'Asqalānī (1992), Dhayl al-Durar al-kāmina, ed. by 'Adnān Darwīsh, Cairo: Ma'had al-Makhțūțāt al-'Arabiyya.

Ibn Ḥajar al-'Asqalānī (1993), al-Durar al-kāmina fí a'yān al-mi'a al-thāmina, ed. n.n., 4 vols., Beirut: Dār al-Jīl.

Ibn Ḥajar al-'Asqalānī (1967-1976), Inbā' al-ghumr bi-abnā' al-'umr, ed. by Muḥammad 'Abd alMu'īd Khān et al., 9 vols., Hyderabad: Dā'irat al-Ma'ārif al-'Uthmāniyya.

Ibn Ḥajar al-'Asqalānī (1969-1998), Inbā’ al-ghumr bi-anbā' al-'umr, ed. by Ḥasan Ḥabashī, 4 vols., Cairo: Lajnat lḥyā' al-Turāth al-Islāmī.

Ibn Ḥajar al-'Asqalānī (1998), Raf' al-ișr 'an qựāt Miṣr, ed. by 'Alī Muḥammad 'Umar, Cairo: Maktabat al-Khānjī.

Ibn Ḥijjī (2003), Ta’rīkh Ibn Ḥijjī, ed. by Abū Yaḥyā 'Abd Allāh al-Kandarī, Beirut: Dār Ibn Ḥazm. Ibn al-'Imād al-Ḥanbalī (1931-1932), Shadharāt al-dhahab fí akhbār man dhahab, ed. n.n., 8 vols., Cairo: Maktabat al-Qudsī (repr. Beirut: Dār lḥyā' al-Turāth al-'Arabī, n.d.).

Ibn lyās (1960-1975), Badā’’' al-zuhūr fĩ waqā’i al-duhūr, ed. by Muḥammad Mușțafā, 5 vols., Cairo - Wiesbaden: Franz Steiner Verlag.

Ibn Khaldūn (1956-1960), Kitāb al-'Ibar, ed. by Yūsuf As'ad Dāghir, Ta'rīkh al-allāma Ibn Khaldūn, 7 vols., Beirut: Dār al-Kitāb al-Lubnānī (repr. 1999).

Ibn Khaldūn (1967), al-Muqaddima, trans. by Franz Rosenthal, The Muqaddimah: An Introduction to History, 2nd ed., 3 vols., New York: Princeton University Press. 
Ibn Khaldūn (1951), al-Ta'rīf bi-Ibn Khaldūn wa-rihlatuhu gharban wa-sharqan, ed. by Muḥammad b. Tāwīt al-Ṭanjī, Cairo: Lajnat al-Ta’lîf wa-l-Tarjama wa-l-Nashr.

Ibn al-Khațīb, Lisān al-Dīn Muḥammad b. 'Abd Allāh (1965), al-Iḥāṭa fi akhbār Gharnāṭa, ed. by Muḥammad 'Abd Allāh 'Inān, 4 vols., Cairo: Maktabat al-Khānjī (repr. 1973).

Ibn al-Khațīb, Lisān al-Dīn Muḥammad b. 'Abd Allāh (1980-1981), Raỵ̣ānat al-kuttāb wa-nuj'at al-muntāb, ed. by Muḥammad 'Abd Allāh 'Inān, 2 vols., Cairo: Maktabat al-Khānjī.

Ibn al-Qāọī al-Miknāsī (1973), Jadhwat al-iqtibās fĩ dhikr man ḥalla min al-alām madīnat Fās, ed. n.n., Rabat: Dār al-Manșūr li-l-Ṭibā'a wa-l-Wirāqa.

Ibn Qāḍi Shuhba (1977-1997), Ta'rīkh Ibn Qāọī Shuhba, ed. by 'Adnān Darwīsh, 4 vols., Damascus: al-Ma'had al-Faransī li-l-Dirāsāt al-'Arabiyya.

Ibn al-Ṣayrafĩ (1970-1994), Nuzhat al-nufūs wa-l-abdān fí tawārīkh al-zamān, ed. by Ḥasan Ḥabashī, 4 vols., Cairo: Dār al-Kutub.

Ibn Taghrībirdī (1984-2009), al-Manhal al-șāfi wa-l-mustawfĩ ba'd al-Wāfĩ, ed. by Muhammad Muḥammad Amīn and Nabīl Muḥammad 'Abd al-'Azīz, 13 vols., Cairo: al-Hay'a al-Miṣriyya al-'Āmma li-l-Kitāb - Dār al-Kutub wa-l-Wathā'iq al-Qawmiyya.

Ibn Taghrībirdī (1929-1972), al-Nujūm al-zāhira fi mulūk Mișr wa-l-Qāhira, ed. n.n., 16 vols., Cairo: al-Hay'a al-Mișriyya al-'Āmma li-l-Kitāb - Dār al-Kutub wa-l-Wathā'iq al-Qawmiyya. Manāqib al-Tilimsāniyyīn (2017), ed. by Qandūz b. Muḥammad al-Māḥī, Rouiba: Dār al-Wa'y. Al-Maqqarī (1968), Naf̣̣ al-țīb min ghuṣn al-Andalus al-rațīb, ed. by Iṇsān 'Abbās, 8 vols., Beirut: Dār Șādir (repr. 1988).

Al-Maqrīzī (2002), Durar al-'uqūd al-farīda fì tarājim al-áyān al-mufĩda, ed. by Maḥmūd alJalīīi, 4 vols., Beirut: Dār al-Gharb al-Islāmī.

Al-Maqrīzī (1853), al-Khițaṭ = al-Mawā'iż wa-l-itibār fi dhikr al-khițaț wa-l-āthār, ed. n.n., 2 vols., Būlāq (repr. Beirut: Dār Șādir, n.d.).

Al-Maqrīzī (2002-2004), al-Khițaț = al-Mawā'ị wa-l-itibār fì dhikr al-khițaț wa-l-āthār, ed. by Ayman Fu'ād Sayyid, 5 vols., London: Mu'assasat al-Furqān li-l-Turāth al-Islāmī.

Al-Maqrīzī (1934-1973), Kitāb al-Sulūk li-márifat duwal al-mulūk, ed. by Muḥammad Mușțafā Ziyāda and Sa'īd 'Abd al-Fattāḥ 'Āshūr, 4 vols., Cairo: Dār al-Kutub.

Al-Qalqashandī (1913-1919), Șubḥ al-a'shā fi șinā'at al-inshā', ed. n.n., 14 vols., Cairo: Dār alKutub.

Al-Sakhāwī (1934-1936), al-Ḍaw' al-lāmi li-ahl al-qarn al-tāsi', ed. n.n., 12 vols., Cairo: Maktabat al-Qudsī (repr. Beirut: Dār Maktabat al-Ḥayāt, n.d.).

Al-Sakhāwī (1349/1930-1), al-Il'ān bi-l-tawbīḥ li-man dhamma al-ta'rīkh, ed. n.n., Damascus: Mațba'at al-Taraqqī.

Al-Suyūțī (1967-1968), Ḥusn al-muhāọara fĩ ta'rīkh Mișr wa-l-Qāhira, ed. by Muḥammad Abū al-Faḍl Ibrāhīm, 2 vols., Cairo: Dār lḥyā’' al-Kutub al-'Arabiyya.

\section{Secondary sources}

Abdesselem, Ahmed (1983), Ibn Khaldun et ses lecteurs, Paris: Presses Universitaires de France.

Alatas, Syed Farid (2013), Ibn Khaldun, Oxford: Oxford University Press.

Al-Azmeh, Aziz (1982), Ibn Khaldūn: An Essay in Reinterpretation, London - New York: Routledge.

Badawī, 'Abd Raḥmān (1962), Mu'allafāt Ibn Khaldūn, Cairo: Dār al-Ma'ārif. 
Bauden, Frédéric (2014), “Taqī al-Dīn Aḥmad ibn 'Alī al-Maqrīzī”, in: Alex Mallett, ed., Medieval Muslim Historians and the Franks in the Levant, Leiden - Boston: Brill, 161-200.

Bel, A., "Ibn Khaldūn, Abū Zakariyyā' Yaḥyā”, The Encyclopaedia of Islam, 2nd ed., 3: 831-832. Benchekroun, Mohamed B. A. (1974), La vie intellectuelle marocaine sous les Mérinides et les Watțāsides (XIII ${ }^{e}, X I V^{e}, X V^{e}, X V l^{e}$ siècles), Rabat.

Bencheneb, H., “al-Sharīf al-Tilimsānī”, The Encyclopaedia of Islam, 2nd ed., 9: 343-348.

Berkel, Maaike van (2009), “al-Qalqashandī”, in: Joseph E. Lowry and Devin J. Steward, eds., Essays in Arabic Literary Biography II: 1350-1850, Wiesbaden: Harrassowitz Verlag, 331340.

Björgman, Walther (1928), Beiträge zur Geschichte der Staatskanzlei im islamischen Ägypten, Hamburg: Friederichsen, de Gruyter \& Co. (repr. Frankfurt am Main: Institute for the History of Arabic-Islamic Science at the Johann Wolfgang Goethe University, 1992).

Bosch-Vilá, J., "Ibn al-Khațīb”, The Encyclopaedia of Islam, 2nd ed., 3: 835-837.

Bosworth, C. E., "al-Ḳalkashandī", The Encyclopaedia of Islam, 2nd ed., 4: 509-511.

Brinner, W. M., "Ibn lyās", The Encyclopaedia of Islam, 2nd ed., 3: 812-813.

Brockelmann, Carl (1996), Geschichte der arabischen Litteratur, 5 vols., Leiden - New York Köln: Brill (repr.).

Cheddadi, Abdesselam (2002), “Introduction”, in: Ibn Khaldūn, Le Livre des Exemples, trans. by Abdesselam Cheddadi, 2 vols., Paris: Gallimard, 2002-2012, 1: ix-xlvi.

Cheddadi, Abdesselam, “Ibn Khaldūn, 'Abd al-Raḥmān”, Encyclopaedia of Islam, THREE, Brill Online.

Darwīsh, 'Adnān (1994), “Muqaddimat al-muḥaqqiq”, in: Ibn Qāọī Shuhba (1977-1997), Ta'rīkh Ibn Qāḍī Shuhba, ed. by 'Adnān Darwīsh, 4 vols., Damascus: al-Ma'had al-Faransī li-lDirāsāt al-'Arabiyya, 2: 11-102 (Ar.)/9-43 (Fr.).

De Moraes Farias, Paulo Fernando, “Aḥmad Bābā al-Tinbuktī”, Encyclopaedia of Islam, THREE, Brill Online.

Delgado Pérez, M. M. (2009), “Ibn al-Azraq, Abū 'Abd Allāh”, in: Jorge Lirola Delgado and José Miguel Puerta Vílchez, eds., Biblioteca de al-Andalus 2: De Ibn Aḍ̣à a Ibn Bušra, Almería: Fundación Ibn Tufayl de Estudios Árabes, 486-490.

Deverdun, G., “Ibn al-Ḳāḍi”, The Encyclopaedia of Islam, 2nd ed., 3: 814.

Fierro, Maribel / Molina, Luis (2009), “al-Maqqarī”, in: Joseph E. Lowry and Devin J. Steward, eds., Essays in Arabic Literary Biography II: 1350-1850, Wiesbaden: Harrassowitz Verlag, 273-283.

Fischel, Walter J. (1952), Ibn Khaldūn and Tamerlane, Berkeley - Los Angeles: University of California Press.

Fischel, Walter J. (1956), “Ibn Khaldūn's Autobiography in the Light of External Arabic Sources”, in: Studi orientalistici in onore di Giorgio Levi della Vida, Rome: Istituto per l'Oriente, 287-308.

Fischel, Walter J. (1967), Ibn Khaldūn in Egypt, Berkeley - Los Angeles: University of California Press.

Frenkel, Yehoshua, "al-Bā'ūnī”, Encyclopaedia of Islam, THREE, Brill Online.

Fromherz, Allen James (2010), Ibn Khaldun, Life and Times, Edinburgh: Edinburgh University Press.

Fromherz, Allen James (2014), “Ibn Khaldūn, Ibn al-Khațīb and Their Milieu: A Community of Letters in the Fourteenth-Century Mediterranean”, Medieval Encounters 20/4-5, 288-305. 
Grammatico, Daniele (2006), “El periplo humano de Ibn Jaldún”, in: Exposición: Ibn Jaldún. El Mediterráneo en el siglo XIV: Auge y declive de los Imperios, Granada: Fundación El Legado Andalusí, 148-157.

Hadj-Sadok, M., “Ibn Marzūḳ”, The Encyclopaedia of Islam, 2nd ed., 3: 865-868.

Idris, H. R., "Ibn 'Arafa”, The Encyclopaedia of Islam, 2nd ed., 3: 712.

Igarashi, Daisuke (2013), “Madrasahs, Their Shaykhs, and the Civilian Founder: The Bāsițīyah Madrasahs in the Mamlūk Era", Orient 43, 79-94.

Igarashi, Daisuke (2017), "The Office of the Ustādār al-'Āliya in the Circassian Mamluk Era”, in: Yuval Ben-Bassat, ed., Developing Perspectives in Mamluk History: Essays in Honor of Amalia Levanoni, Leiden - Boston: Brill, 115-142.

Irwin, Robert (2003), “Al-Maqrīzī and Ibn Khaldūn, Historians of the Unseen”, Mamlūk Studies Review 7/2, 217-230.

Irwin, Robert (2018), Ibn Khaldun: An Intellectual Biography, Princeton - Oxford: Princeton University Press.

Isahak, Aldila (2010), Ibn al-Azraq's Political Thought: A Study of Bada'i' al-Silk fi Taba'i' alMulk, Saarbrücken: VDM Verlag Dr. Müller.

Ito, Takao (2015), “Al-Maqrīzī’s Biography of Tīmūr”, Arabica 62, 308-327.

Al-Jalīlī, Maḥmūd (1966), “Tarjamat Ibn Khaldūn li-l-Maqrīzī”, Majallat al-Majma' al-iilmī alirāqī 13, 215-242.

Knysh, Alexander D. (1999), Ibn 'Arabi in the Later Islamic Tradition, Albany: State University of New York Press.

Kugle, Scott, “Zarrūq, Ahmad”, Encyclopaedia of Islam, THREE, Brill Online.

Lévi-Provençal, E. / Pellat. Ch., "al-Maḳkarī”, The Encyclopaedia of Islam, 2nd ed., 6: 187-188.

Lirola Delgado, J. / Arié, R. / Garijo Galán, I. / Molina López, E., / Puerta Vílchez, J. M. / Vázquez de Benito, M. C. (2004), “Ibn al-Jațīb al-Salmānī, Lisān al-Dīn”, in: Jorge Lirola Delgado and José Miguel Puerta Vílchez, eds., Biblioteca de al-Andalus 3: De Ibn al-Dabbāg a lbn Kurz, Almería: Fundación Ibn Tufayl de Estudios Árabes, 643-698.

Manzano Rodríguez, M. Á. (2009), “Ibn al-Aḥmar al-Anșārī, Abū l-Walīd”, in: Jorge Lirola Delgado and José Miguel Puerta Vílchez, eds., Biblioteca de al-Andalus 2: De Ibn Aḍhà a lbn Bušra, Almería: Fundación Ibn Tufayl de Estudios Árabes, 53-60.

Marmon, Shaun E., “al-'Aynī, Badr al-Dīn”, Encyclopaedia of Islam, THREE, Brill Online.

Massoud, Sami G. (2007), The Chronicles and Annalistic Sources of the Early Mamluk Circassian Period, Leiden - Boston: Brill.

Massoud, Sami G., “Ibn Hiijjī”, Encyclopaedia of Islam, THREE, Brill Online.

McChesney, R. D. (2006), “A Note on the Life and Works of Ibn 'Arabshāh”, in: Judith Pfeiffer, Sholeh A. Quinn, and Ernest Tucker, eds., History and Historiography of Post-Mongol Central Asia and the Middle East, Wiesbaden: Harrossowitz Verlag, 205-249.

Morimoto, Kosei (2002), "What Ibn Khaldūn Saw: The Judiciary of Mamluk Egypt”, Mamlūk Studies Review 6, 109-131.

Al-Musawi, Muhsin J. (2015), The Medieval Islamic Republic of Letters, Notre Dame, Indiana: University of Notre Dame Press.

Nakamachi, Nobutaka (2005), “Al-'Aynī's Chronicles as a Source for the Baḥrī Mamluk Period”, Orient (Journal of the Society for Near Eastern Studies in Japan) 40, 140-171.

Oumlil, Ali (1982), L'histoire et son discours: Essai sur la methodologie d'lbn Khaldoun, Rabat: Société Marocaine des Éditeurs Réunis. 
Özer, Yumna (2017), “Translator’s Introduction”, in: Ibn Khaldūn on Sufism: Remedy for the Questioner in Search of Answers: Shifä' al-Sā'il li-Tahdhīb al-Masāìl, trans. by Yumna Özer, Cambridge: The Islamic Text Society, ix-xli.

Peláez Rovira, A. (2006), “Ibn Marzūq, Abū 'Abd Allāh”, in: Jorge Lirola Delgado, ed., Biblioteca de al-Andalus 4: De Ibn al-Labbāna a Ibn al-Ruyūlī, Almería: Fundación Ibn Tufayl de Estudios Árabes, 124-138.

Petry, C. F., "al-Sakhāwī”, The Encyclopaedia of Islam, 2nd ed., 8: 881-882.

Popper, W., “Abū 'l-Maḥāsin, Djamāl al-Dīn Yūsuf b. Taghrībirdī”, The Encyclopaedia of Islam, 2nd ed., 1: 138.

Puente, C. de la, "al-Balafĩqī", Encyclopaedia of Islam, THREE, Brill Online.

Puente, C. de la (2012), "al-Balafĩqī, Abū l-Barakāt”, in: Jorge Lirola Delgado and José Miguel Puerta Vílchez, eds., Biblioteca de al-Andalus 1: De al-Abbādīya a Ibn Abyaḍ, Almería: Fundación Ibn Tufayl de Estudios Árabes, 160-164.

Reisman, David C. (1998), “A Holograph MS of Ibn Qāḍī Shuhbah's 'Dhayl”, Mamlūk Studies Review 2, 19-49.

Ritter, Helmut (1953), “Autographs in Turkish Libraries”, Oriens 6/1, 63-90.

Robinson, Cynthia (2009), “Lisān al-Dīn Ibn al-Khațīb”, in: Joseph E. Lowry and Devin J. Steward, eds., Essays in Arabic Literary Biography II: 1350-1850, Wiesbaden: Harrassowitz Verlag, 159-174.

Romanov, Maxim (2017), “Algorithmic Analysis of Medieval Arabic Biographical Collections”, Speculum 92/S1, S226-S246.

Rosenthal, Franz (1967), “Translator's Introduction”, in: Ibn Khaldūn, The Muqaddimah: An Introduction to History, trans. by Franz Rosenthal, 2nd ed., 3 vols., New York: Princeton University Press, 1: xxvii-cxv.

Rosenthal, Franz (1968), A History of Muslim Historiography, 2nd ed., Leiden: E. J. Brill.

Rosenthal, Franz (1984), “Ibn Khaldun in His Time”, in: Bruce B. Lawrence, ed., Ibn Khaldun and Islamic Ideology, Leiden: E. J. Brill, 14-26.

Rosenthal, Franz (2000), “Ibn Khaldūn's Biography Revisited”, in: Ian Richard Netton, ed., Studies in Honour of Clifford Edmund Bosworth, Volume 1. Hunter of the East: Arabic and Semitic Studies, Leiden - Boston - Köln: Brill, 40-63.

Rosenthal, F., “al-Fāsī”, The Encyclopaedia of Islam, 2nd ed., 2: 828-829.

Rosenthal, F., “Ibn Ḥadjar al-'Asḳalānī”, The Encyclopaedia of Islam, 2nd ed., 3: 776-778.

Rosenthal, F., "Ibn al-'Imād”, The Encyclopaedia of Islam, 2nd ed., 3: 807.

Shatzmiller, Maya (1982), L'Historiographie Mérinide: Ibn Khaldūn et ses contemporains, Leiden: E. J. Brill.

Simon, Róbert (2002), Ibn Khaldūn: History as Science and the Patrimonial Empire, trans. by Klára Pogátsa, Budapest: Akadémiai Kiadó. 
